\title{
Meningkatkan Hasil Belajar Matematika Kelas V SD Melalui Media Video Pembelajaran
}

\section{Ni Komang Widiarti ${ }^{*}$, I Komang Sudarma ${ }^{2}$, I Made Tegeh ${ }^{3}$}

1,2,3 Program Studi Teknologi Pendidikan, Singaraja, Universitas Pendidikan Ganesha, Indonesia

\section{A R T I C L E I N F O}

Article history:

Received August 10, 2021

Revised August 12, 2021

Accepted September 30, 2021

Available online December 25, 2021

Kata Kunci:

Media Video Pembelajaran, HOTS ADDIE

Keywords:

Learning Video Media, HOTS, ADDIE

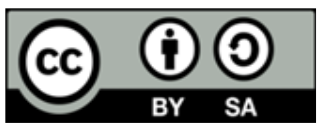

This is an open access article under the CC BY-SA license.

Copyright $(2021$ by Author. Published by Universitas Pendidikan Ganesha.

\begin{abstract}
A B S T R A K
Pembelajaran yang masih bersifat konvensional dan hasil belajar siswa yang rendah merupakan permasalahan utama dalam penelitian ini. Untuk itu diperlukan adanya media pembelajaran yang mampu menunjang pembelajaran dan dapat mengoptimalkan pemanfaatan fasilitas di sekolah. Tujuan penelitian ini yaitu untuk mendeskripsikan rancang bangun media video pembelajaran berbasis Higher Order Thinking Skills (HOTS) dan untuk mengetahui validitas media video pembelajaran berbasis Higher Order Thinking Skills (HOTS). Penelitian ini menggunakan jenis penelitian pengembangan dengan model ADDIE. Subjek penelitian ini yaitu 1 orang sebagai ahli isi pembelajaran, 1 orang sebagai ahli desain pembelajaran, 1 orang sebagai ahli media pembelajaran, 3 orang siswa sebagai uji coba perorangan, dan 9 orang siswa sebagai uji coba kelompok kecil. Metode pengumpulan data menggunakan metode pencatatan dokumen dan kuesioner dengan menggunakan instrumen lembar pencatatan dokumen dan lembar kuesioner. Teknik analisis data yaitu menggunakan teknik analisis deskriptif kualitatif dan kuantitatif. Kualitas media video pembelajaran ini mendapat hasil validitas yaitu melalui hasil review ahli isi pembelajaran dengan kualifikasi sangat baik (96\%), hasil review ahli desain pembelajaran dengan kualifikasi baik (86,67\%), hasil review ahli media pembelajaran dengan kualifikasi sangat baik $(94 \%)$, hasil uji coba perorangan dengan kualifikasi sangat baik $(92,22 \%)$ dan hasil uji coba kelompok kecil dengan kualifikasi sangat baik $(96,67 \%)$. Media video pembelajaran ini berada pada kualifikasi sangat baik dan baik maka layak untuk digunakan dalam proses pembelajaran. Selain itu, media ini berimplikasi terhadap minat belajar siswa serta memotivasi guru dalam mengembangkan media pembelajaran lainnya.
\end{abstract}

\section{A B S T R A C T}

Learning that is still conventional and low student learning outcomes are the main problems in this study. Thus, it is necessary to have learning media that are able to support learning and can optimize the use of facilities in schools. The purpose of this study is to describe the design of learning video media based on Higher Order Thinking Skills (HOTS), and to determine the validity of learning video media based on Higher Order Thinking Skills (HOTS). This study uses a type of development research with the ADDIE model. The subjects of this study were 1 person as a learning content expert, 1 person as an instructional design expert, 1 person as a learning media expert, 3 students as individual trials, and 9 students as small group trials. The method of data collection using the method of recording documents and questionnaires using the instrument of document recording sheets and questionnaire sheets. The data analysis technique is using qualitative and quantitative descriptive analysis techniques. The quality of this instructional video media got validity results, namely through the results of the review of learning content experts with very good qualifications (96\%), the results of reviews of learning design experts with good qualifications (86.67\%), the results of the reviews of learning media experts with very good qualifications (94\%), the results of individual trials with very good qualifications (92.22\%) and the results of small group trials with very good qualifications (96.67\%). This learning video media is in very good and good qualifications, so it is feasible to be used in the learning process. In addition, this media has implications for students' interest in learning and motivates teachers in developing other learning media. 


\section{PENDAHULUAN}

Lahirnya pendidikan 4.0 merupakan fenomena baru yang dipengaruhi oleh revolusi industri yang berpengaruh besar terhadap beberapa sektor. Pada pendidikan 4.0 ini diharapkan mampu menyelesaikan masalah serta menemukan solusi hingga memunculkan inovasi baru. Guru memiliki peran penting dalam pembelajaran melalui kemampuan merancang dan melaksanakan proses pembelajaran, sehingga peningkatan inovasi pada bidang pendidikan di Indonesia masih terus diupayakan (Lubis, 2020; Oktavian \& Aldya, 2020; Susanto, 2017). Sampai saat ini, sekolah masih menggunakan Kurikulum 2013 memiliki tujuan untuk menghasilkan manusia yang kreatif, kritis, dan inovatif. Berdasarkan hasil analisis kebutuhan di lapangan ditemukan bahwa fasilitas yang dimiliki untuk menunjang proses pembelajaran adalah laptop, LCD Proyektor, dan HP. Jika dilihat dari permasalahan guru dalam menyampaikan pembelajaran, sebesar $50 \%$ guru menyatakan bahwa guru memiliki kesulitan dalam menyampaikan konsep abstrak, 33,33\% guru kesulitan untuk mengajak siswa fokus, dan $16,67 \%$ kesulitan menyampaikan pembelajaran secara daring. Dilihat dari mata pelajaran yang memiliki permasalahan dalam pembelajarannya, sebesar $50 \%$ guru menyatakan bahwa mata pelajaran yang memiliki permasalahan dalam pembelajarannya adalah Matematika, 33,33\% Matematika dan IPA, dan 16,67\% Matematika dan PKN. Sebesar 83,33\% guru menyatakan bahwa masih menggunakan media yang bersifat konvensional. Berdasarkan data awal tersebut, guru di SD Negeri 1 Baktiseraga memerlukan media pembelajaran yang mampu menyampaikan konsep abstrak dan mampu mengajak siswa fokus dalam pembelajaran. Hasil observasi tersebut sesuai dengan sesuai dengan pernyataan bahwa proses pembelajaran diperlukan media yang inovatif untuk menjelaskan materi yang abstrak dan terinci hanya dengan teks naratif (Azmi et al., 2020; Daheri et al., 2020).

Hasil belajar siswa yang ditemukan yang ebih banyak memiliki hasil belajar di bawah KKM adalah pada mata pelajaran Matematika kelas V. Berdasarkan jumlah siswa yang terdiri dari 28 siswa, terdapat 21 siswa yang hasil belajarnya berada di bawah KKM dengan KKM 68. Sesuai dengan hasil pengisian angket yang diberikan kepada siswa kelas V di SD Negeri 1 Baktiseraga, sebanyak 33,33\% siswa sangat setuju dan $66,67 \%$ setuju bahwa siswa lebih memahami pelajaran setelah guru menggunakan media pembelajaran seperti video, gambar, dll. Sebanyak $27,78 \%$ siswa sangat setuju dan $61,11 \%$ setuju bahwa siswa merasa bosan jika kegiatan belajar mengajar tidak menggunakan media pembelajaran. Sebanyak $11,11 \%$ siswa sangat setuju dan $44,44 \%$ setuju bahwa guru hanya menggunakan satu jenis media saja. Sebanyak 38,89\% siswa sangat setuju dan $55,56 \%$ setuju bahwa siswa merasa lebih terbantu memahami materi setelah guru menggunakan media pembelajaran. Sebanyak $16,67 \%$ siswa sangat setuju dan $50 \%$ setuju bahwa siswa lebih senang menggunakan media audio visual (video) daripada menggunakan media cetak (LKS, Modul, dan lain-lain). Maka, siswa lebih senang dan dapat membantu mereka dalam memahami materi jika pembelajaran menggunakan media pembelajaran berbasis video. Pembelajaran perlu memanfaatkan media sehingga berlangsung efektif dan efisien dan motivasi serta hasil belajar siswa meningkat(Soimah, 2018; Susilo, 2020).

Kesenjangan yang terjadi antara kondisi nyata dengan kondisi yang diharapkan jika tidak ditindaklanjuti maka akan berdampak terhadap rendahnya motivasi, minat, serta hasil belajar siswa. Permasalahan mengenai pembelajaran yang bersifat konvensional dan hasil belajar siswa yang rendah dapat diatasi dengan cara menggunakan media pembelajaran yang menarik minat belajar siswa. Media yang diperlukan adalah media yang mampu menyampaikan pembelajaran dengan visual yang menarik dan memotivasi siswa untuk berkonsentrasi dalam pembelajaran serta dapat dipelajari secara berulang-ulang. Media video merupakan media yang efektif jika digunakan dalam dalam proses pembelajaran yang dapat meningkatkan motivasi belajar siswa melalui visual dan audio (Rahman et al., 2019; Syafi'i et al., 2020). Penggunaan media video untuk menyampaikan materi dapat menarik perhatian siswa agar fokus dalam pembelajaran (Coles, 2019; Musthofa \& Murdani, 2018; Wirasasmita \& Putra, 2018). Media video pembelajaran ini dipilih karena video dapat membantu pendidik dalam mengajarkan konsep dari materi dan menjelaskan hal abstrak menjadi konkret karena menyajikan informasi dalam bentuk teks, gambar, dan suara (Nurdin et al., 2019; Pangestu et al., 2019). Literasi matematika memiliki konteks untuk menyelesaikan permasalahan yang ada pada kehidupan nyata, sehingga bukan sekadar menghafal namun menghubungkan konsep-konsep yang didapatkannya kemudian memformulasikan solusi sesuai konteks yang terjadi (Fitriani et al., 2018; Nurkamilah et al., 2018; Pasandaran, 2018). Mata pelajaran Matematika seharusnya dibekali mulai dari sekolah dasar, sehingga mampu mengasah kemampuan berpikir logis, analitis, sistematis, kritis, dan kreatif, dan kemampuan bekerja sama (Kasri, 2018; Lestari \& Roesdiana, 2021; Suryawan et al., 2017). Pembelajaran HOTS dapat memicu siswa untuk berpikir kritis menuntut penggunaan strategi pembelajaran yang berorientasi pada siswa aktif, sehingga siswa memiliki kesempatan untuk mengamati, menanya, menalar, mencoba, dan mengomunikasikan (Fanani \& Kusmaharti, 2018; Utaminingtyas, 2020). HOTS merupakan suatu cara untuk membangun nalar, kreativitas, serta pemecahan 
masalah dengan menggunakan kemampuan analisis, sintesis, dan evaluasi (Nguyen \& Nguyen, 2017; Pratama \& Retnawati, 2018).

Mengacu pada pemaparan di atas, dipandang perlu adanya media pembelajaran inovatif yang dapat membantu siswa dalam belajar yaitu dengan pengembangan media video pembelajaran berbasis HOTS pada pembelajaran Matematika siswa SD. Penelitian pengembangan ini didukung oleh hasil penelitian yang sudah ada sebelumnya, yaitu hasil penelitian yang menunjukkan bahwa media video pembelajaran dinyatakan efektif untuk digunakan dalam proses pembelajaran, yang terbukti dari hasil belajar siswa memiliki peningkatan (Haking \& Soepriyanto, 2019; Melinda et al., 2018). Penelitian ini didukung juga oleh hasil penelitian yang menunjukkan bahwa penggunaan video pembelajaran dapat meningkatkan kemampuan berpikir tingkat tinggi membantu merangsang daya kritis siswa (Endriani et al., 2018; Ichsan et al., 2018). Berdasarkan hasil penelitian tersebut, tentu saja memperkuat bahwa media video pembelajaran sangat bermanfaat dalam proses pembelajaran dan memiliki kemungkinan yang baik pula untuk dikembangkan lebih lanjut dengan subjek penelitian yang berbeda. Dengan demikian, maka dapat disimpulkan bahwa media video pembelajaran ini dapat membuat pembelajaran menjadi efektif dan mampu meningkatkan kemampuan berpikir tingkat tinggi dan hasil belajar siswa. Penelitian ini memiliki perbedaan dengan penelitian yang lain yaitu media video pembelajaran berbasis HOTS di dalamnya menyajikan animasi yang mampu menarik minat siswa untuk belajar. Selain itu, materi yang disajikan adalah materi operasi hitung pecahan pada mata pelajaran Matematika yang materinya berbeda dengan penelitian lain. Tujuan penelitian ini yaitu untuk mendeskripsikan rancang bangun media video pembelajaran berbasis HOTS, dan untuk mengetahui validitas media video pembelajaran berbasis HOTS.

\section{METODE}

Jenis penelitian ini yaitu penelitian pengembangan yang dilaksanakan pada siswa kelas $\mathrm{V}$ di SD Negeri 1 Baktiseraga dengan menggunakan model ADDIE, terdiri atas lima langkah, yaitu analisis (analysis), perancangan (design), pengembangan (development), implementasi (implementation), dan evaluasi (evaluation). Tahapan ADDIE dilakukan secara teratur dan berpedoman pada landasan teoretis desain pembelajaran yaitu mempertimbangkan masalah pembelajaran serta dilakukan beberapa kali revisi untuk penyempurnaan (Cahyadi, 2019; Tegeh \& Jampel, 2017). Jika dilihat dari pemaparan tersebut, maka pengembang memilih model ADDIE sebagai pedoman pengembangan media karena menggambarkan pendekatan sistematis untuk pengembangan instruksional serta bertumpu pada landasan teoretis desain pembelajaran. Penelitian pengembangan ini dilaksanakan pada siswa kelas V di SD Negeri 1 Baktiseraga. Subjek pada penelitian ini yaitu 1 ahli isi pembelajaran, 1 ahli desain pembelajaran, 1 ahli media pembelajaran, 3 siswa untuk uji coba perorangan, dan 9 siswa untuk uji coba kelompok kecil. Penelitian pengembangan ini menggunakan dua metode pengumpulan data, yaitu metode pencatatan dokumen dan metode kuesioner. Instrumen pengumpulan data pada penelitian ini menggunakan dua instrumen pengumpulan data yaitu lembar pencatatan dokumen dan lembar kuesioner. Lembar pencatatan dokumen digunakan untuk mengumpulkan data-data proses pengembangan produk media video pembelajaran sesuai dengan model pengembangan ADDIE yang dirancang berupa laporan pengembangan produk media video pembelajaran secara ringkas. Sedangkan, lembar kuesioner pada penelitian pengembangan ini dibuat untuk mengukur validitas produk media video pembelajaran yang dikembangkan. Lembar kuesioner yang dimaksud adalah validasi hasil review oleh ahli isi pembelajaran, ahli desain pembelajaran, ahli media pembelajaran, tanggapan siswa saat uji coba perorangan, dan uji coba kelompok kecil. Berikut merupakan kisi-kisi instrumen validasi para ahli dan uji coba disajikan pada Tabel 1, 2, 3, dan 4.

Tabel 1. Kisi-Kisi Instrumen Validasi Ahli Isi Pembelajaran

\begin{tabular}{|c|c|c|c|}
\hline No. & Aspek & Indikator & Jumlah \\
\hline 1 & Kesesuaian video & $\begin{array}{l}\text { a. Kesesuaian tujuan pembelajaran } \\
\text { b.Tujuan pembelajaran sesuai dengan format ABCD } \\
\text { c. Kesesuaian materi pada video }\end{array}$ & 3 \\
\hline 2 & $\begin{array}{l}\text { Kejelasan } \\
\text { pesan/materi }\end{array}$ & $\begin{array}{l}\text { a. Kejelasan materi yang disajikan } \\
\text { b.Sistematika materi yang disajikan }\end{array}$ & 2 \\
\hline 3 & Representasi Isi & $\begin{array}{l}\text { a. Mampu menarik minat dan motivasi belajar siswa } \\
\text { b. Kesesuaian contoh dengan pembelajaran HOTS } \\
\text { c. Sesuai pada tingkat kematangan siswa } \\
\text { d.Perbendaharaan bahasa yang baik }\end{array}$ & 4 \\
\hline 4 & User Friendly & a. Kemudahan pemakai dalam mengakses media & 1 \\
\hline
\end{tabular}


Tabel 2. Kisi-Kisi Instrumen Validasi Ahli Desain Pembelajaran

\begin{tabular}{|c|c|c|c|}
\hline No. & Aspek & Indikator & Jumlah \\
\hline 1 & Kesesuaian video & $\begin{array}{l}\text { a. Kesesuaian tujuan pembelajaran } \\
\text { b.Tujuan pembelajaran sesuai dengan format ABCD } \\
\text { c. Kesesuaian materi pada video } \\
\text { d.Materi dalam video pembelajaran dikemas secara } \\
\text { runtut }\end{array}$ & 4 \\
\hline 2 & Visualisasi media & $\begin{array}{l}\text { a. Ketepatan warna yang disajikan } \\
\text { b. Ketepatan jenis dan ukuran huruf pada video } \\
\text { c. Ketepatan penulisan ejaan pada materi } \\
\text { d.Ketepatan ilustrasi dengan deskripsi }\end{array}$ & 4 \\
\hline 3 & Representasi Isi & $\begin{array}{l}\text { a. Mampu menarik minat dan motivasi belajar siswa } \\
\text { b.Sesuai pada tingkat kematangan siswa } \\
\text { c. Perbendaharaan bahasa yang baik }\end{array}$ & 3 \\
\hline 4 & Clarity of Massage & $\begin{array}{l}\text { a. Dapat memberikan pemahaman pesan pembelajaran } \\
\text { secara lebih bermakna }\end{array}$ & 1 \\
\hline & & Jumlah & 12 \\
\hline
\end{tabular}

Tabel 3. Kisi-Kisi Instrumen Validasi Ahli Media Pembelajaran

\begin{tabular}{|c|c|c|c|}
\hline No. & Aspek & Indikator & Jumlah \\
\hline 1 & Visualisasi media & $\begin{array}{l}\text { a. Kemenarikan sajian animasi yang ditampilkan } \\
\text { b.Kemenarikan sajian gambar yang ditampilkan } \\
\text { c. Kemenarikan sajian teks yang ditampilkan } \\
\text { d.Dapat meningkatkan motivasi siswa dalam } \\
\quad \text { pembelajaran }\end{array}$ & 4 \\
\hline 2 & Durasi waktu & a. Ketepatan warna yang disajikan & 1 \\
\hline 3 & $\begin{array}{l}\text { Penggunaan narasi, } \\
\text { musik dan sound effect }\end{array}$ & $\begin{array}{l}\text { a. Kejelasan suara narator } \\
\text { b. Keteraturan musik latar } \\
\text { c. Ketepatan sound effect yang digunakan untuk } \\
\text { menambah suasana dan melengkapi sajian visual }\end{array}$ & 3 \\
\hline 4 & User Friendly & a. Kemudahan dalam menggunakan media & 1 \\
\hline 5 & Stand Alone & $\begin{array}{l}\text { a. Dalam penggunaan media tidak bergantung dengan } \\
\text { bahan ajar lain }\end{array}$ & 1 \\
\hline & & Jumlah & 10 \\
\hline
\end{tabular}

Tabel 4. Kisi-Kisi Instrumen Uji Coba Perorangan dan Kelompok Kecil

\begin{tabular}{|c|c|c|c|}
\hline No. & Aspek & Indikator & Jumlah \\
\hline 1 & User Friendly & a. Kemudahan dalam menggunakan media & 1 \\
\hline 2 & Stand Alone & $\begin{array}{l}\text { a. Dalam penggunaan media tidak bergantung dengan bahan ajar } \\
\text { lain }\end{array}$ & 1 \\
\hline \multirow[t]{10}{*}{3} & Representasi & a. Petunjuk belajar pada video jelas & 10 \\
\hline & Isi & b. Kejelasan materi yang disajikan & \\
\hline & & c. Kejelasan pada teks yang disajikan & \\
\hline & & $\begin{array}{l}\text { d.Penggunaan gambar pada video mempermudah memahami } \\
\text { video }\end{array}$ & \\
\hline & & e. Materi yang disajikan mudah dipahami & \\
\hline & & f. Contoh yang disajikan mampu memotivasi siswa & \\
\hline & & g. Kemenarikan visual yang disajikan & \\
\hline & & h.Video pembelajaran mampu meningkatkan motivasi belajar & \\
\hline & & i. Sesuai pada tingkat kematangan siswa & \\
\hline & & j. Media yang dikembangkan sesuai dengan karakteristik siswa & \\
\hline
\end{tabular}

Sumber: berdasarkan teori dari Riyana (dalam Usman \& Husnan, 2020) 
Penelitian ini menggunakan dua teknik analisis data, yaitu analisis deskriptif kualiatif dan kuantitatif. Metode analisis deskriptif kualitatif yaitu pengolahanan data yang berupa kalimat/kata-kata, kategori tentang objek secara sistematis, sehingga memperoleh kesimpulan umum (Agung, 2017; Zaluchu, 2020). Teknik analisis deskriptif kualitatif ini digunakan untuk mengolah masukan, komentar, saran dari para ahli dan uji coba. Metode analisis deskriptif kuantitatif yaitu pengolahan data yang berupa angka/persentase tentang objek sehingga memperoleh kesimpulan umum (Agung, 2017; Zaluchu, 2020). Teknik analisis deskriptif kuantitatif ini digunakan untuk mengolah data hasil penilaian dari para ahli dan uji coba.

\section{HASIL DAN PEMBAHASAN}

Hasil

Rancang bangun media video pembelajaran berbasis higher order thinking skills ini mengacu pada tahapan model pengembangan ADDIE yaitu tahap analisis (analysis). Pada tahap ini dilakukan proses observasi lingkungan sekolah, membagikan kuesioner analisis kebutuhan kepada guru di SD Negeri 1 Baktiseraga, dan melakukan wawancara dengan guru kelas V mengenai karakteristik siswa, permasalahan belajar, serta melakukan analisis kompetensi, sehingga dapat dapat disimpulkan mengenai kebutuhan dalam pembelajaran matematika kelas V di SD Negeri 1 Baktiseraga. Tahap desain (design), pada tahap ini dilakukan proses pemilihan dan penetapan perangkat lunak/software, perangkat lunak/software yang digunakan adalah Wondershare Filmora X yang digunakan untuk proses editing media video pembelajaran, selain itu juga dibantu aplikasi yang lain yaitu Adobe Photoshop CS5.1, Adobe Flash Professional CS5.5, CorelDraw X7, dan Adobe Audition CS5.5. Selanjutnya, merancang flowchart, storyboard dan storyline yang digunakan sebagai pedoman untuk merancang alur cerita. Menyusun instrumen digunakan untuk menilai validitas produk yang telah dikembangkan, pada setiap instrumen diuji validitas butir instrumennya oleh penguji yang berbeda-beda, seperti instrumen ahli desain pembelajaran, ahli media pembelajaran, dan uji coba perorangan, serta uji coba kelompok kecil. Perancangan yang terakhir adalah menyusun RPP. Hasilnya ditunjukkan pada Tabel 5.

Tabel 5. KD dan Indikator Operasi Hitung Pecahan

\begin{tabular}{lc}
\hline Kompetensi Dasar & Indikator \\
\hline $\begin{array}{l}\text { 3.1. Menguraikan } \\
\text { penjumlahan dan }\end{array}$ & 3.1.1 Menguraikan tentang penjumlahan dan pengurangan pecahan \\
pengurangan pecahan & 3.1.2 Memecahkan permasalahan penjumlahan dan pengurangan \\
pecahan dalam kehidupan sehari-hari \\
$\begin{array}{l}\text { 3.3. Menguraikan perkalian } \\
\text { pecahan dan pembagian } \\
\text { pecahan }\end{array}$ & $\begin{array}{c}\text { 3.3.1 Menguraikan tentang perkalian dan pembagian pecahan } \\
\text { 3.3.2 Memecahkan permasalahan perkalian dan pembagian pecahan } \\
\text { dalam kehidupan sehari-hari }\end{array}$ \\
\hline
\end{tabular}

Tahap pengembangan (development), pada tahap ini dilakukan proses pengumpulan bahan seperti gambar, sound effect, dan backsound. Selanjutnya, dilakukan pembuatan animasi menggunakan Adobe Flash Professional CS5.5, gambar, dan baground menggunakan CorelDraw X7. Kemudian, dilakukan perekaman suara menggunakan Adobe Audition CS5.5 serta editing video menggunakan Filmora X. Tahap implementasi (implementation), tahapan implementasi merupakan tahapan untuk melakukan uji validitas dan uji coba produk untuk kelayakan media yang telah dikembangkan. Validasi produk melalui review dari para ahli, yaitu ahli isi pembelajaran seorang dosen program studi PGSD, Undiksha, ahli desain pembelajaran seorang dosen program studi Teknologi Pendidikan, dan ahli media pembelajaran juga seorang dosen program studi Teknologi Pendidikan. Uji coba perorangan menggunakan responden sebanyak 3 (tiga) orang siswa dari kelas V pada SD Negeri 1 Baktiseraga, yang terdiri dari 1 orang siswa dari hasil belajar tinggi, 1 orang siswa dari hasil belajar sedang, dan 1 orang siswa dari hasil belajar rendah. Sedangkan, uji coba kelompok kecil menggunakan responden sebanyak 9 (sembilan) orang siswa dari kelas V pada SD Negeri 1 Baktiseraga, yang terdiri dari 3 orang siswa dari hasil belajar tinggi, 3 orang siswa dari hasil belajar sedang, dan 3 orang siswa dari hasil belajar rendah. Tahap evaluasi (evaluation), pada tahap ini dilakukan evaluasi dan revisi sesuai dengan review para ahli, uji coba perorangan, dan kelompok kecil yang dilakukan untuk meningkatkan kelayakan media video pembelajaran. Hasil validitas media video pembelajaran disajikan pada Tabel 5. 
Tabel 5. Hasil Uji Validitas Produk

\begin{tabular}{clcc}
\hline No. & \multicolumn{1}{c}{ Subjek Uji Coba } & Hasil Validitas & Keterangan \\
\hline 1 & Uji Ahli Isi Pembelajaran & $96 \%$ & Sangat Baik \\
2 & Uji Ahli Desain Pembelajaran & $86,67 \%$ & Baik \\
3 & Uji Ahli Media Pembelajaran & $94 \%$ & Sangat Baik \\
4 & Uji Coba Perorangan & $92,22 \%$ & Sangat Baik \\
5 & Uji Coba Kelompok Kecil & $96,67 \%$ & Sangat Baik \\
\hline
\end{tabular}

Hasil penilaian yang dilakukan oleh ahli isi pembelajaran dikonversi melalui tingkat pencapaian skala 5 diperoleh persentase sebesar 96\%, dengan kualifikasi sangat baik. Hasil penilaian yang dilakukan oleh ahli desain pembelajaran dikonversi melalui tingkat pencapaian skala 5, diperoleh persentase sebesar 86,67\%, dengan kualifikasi baik. Hasil penilaian yang dilakukan oleh ahli media pembelajaran dikonversi melalui tingkat pencapaian skala 5 diperoleh persentase sebesar 94\%, dengan kualifikasi sangat baik. Hasil penilaian yang dilakukan oleh 3 orang siswa melalui uji coba perorangan dikonversi melalui tingkat pencapaian skala 5 diperoleh persentase sebesar 92,22\% dengan kualifikasi sangat baik. Hasil penilaian yang dilakukan oleh 9 orang siswa melalui uji coba kelompok kecil dikonversi melalui tingkat pencapaian skala 5 diperoleh persentase sebesar $96,67 \%$ dengan kualifikasi sangat baik. Hasil ini menunjukkan bahwa media video pembelajaran berbasis higher order thinking skills berada pada kualifikasi sangat baik dan baik serta layak digunakan dalam proses pembelajaran pada pembelajaran matematika kelas V di SD Negeri 1 Baktiseraga. Kelayakan produk masukan, saran, dan komentar tersebut digunakan sebagai dasar perbaikan produk. Tampilan media video pembelajaran disajikan pada Gambar 1.

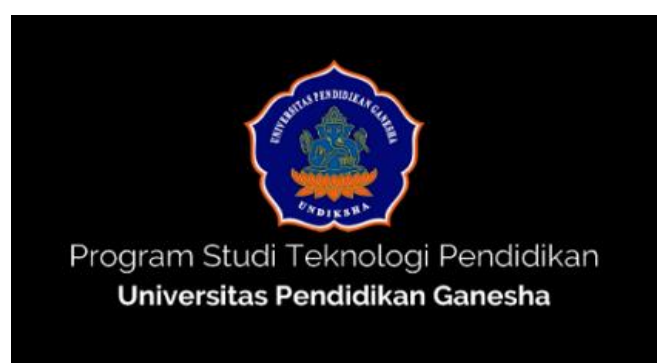

Tampilan awal video

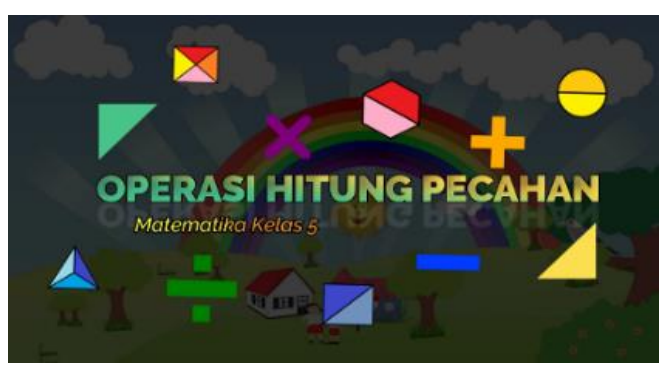

Tampilan animasi judul

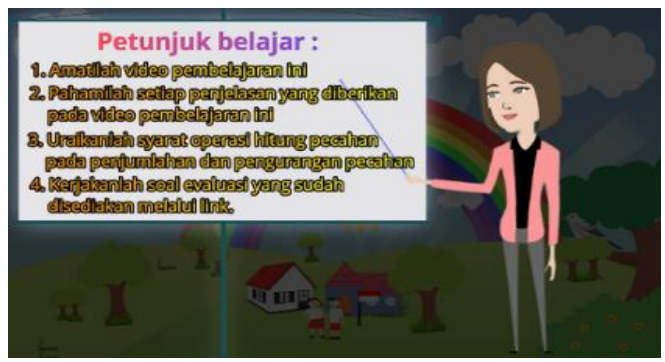

Petunjuk belajar

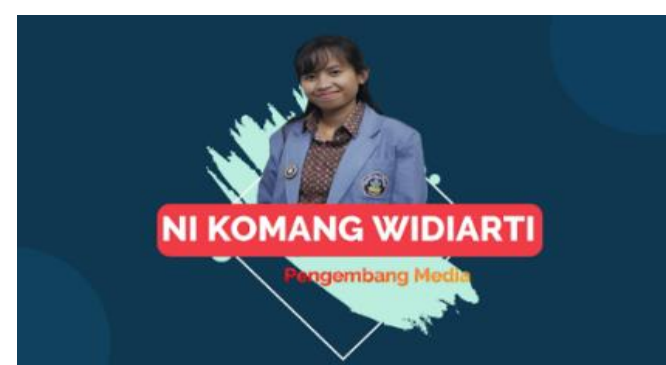

Tampilan identitas

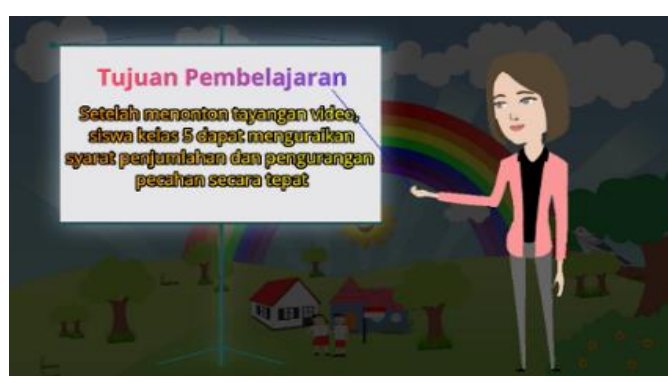

Tujuan pembelajaran

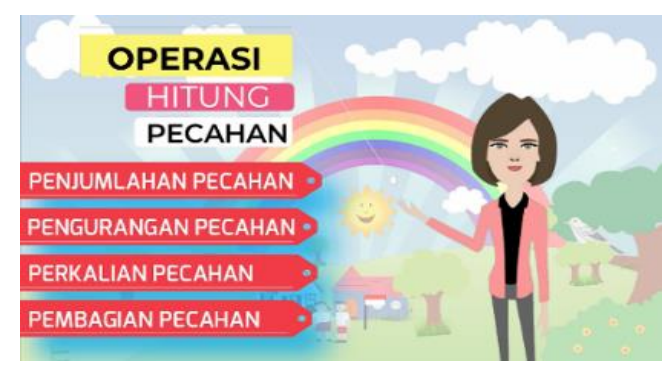

Tampilan isi materi 


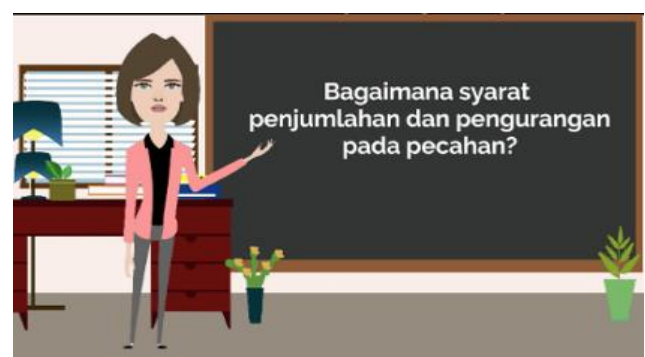

Tampilan soal 1

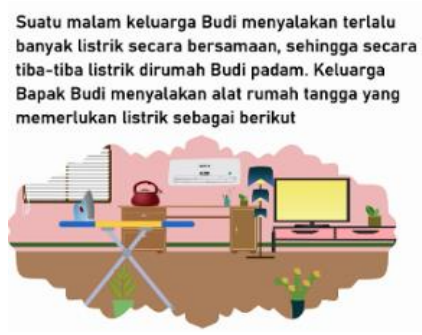

Tampilan soal 3

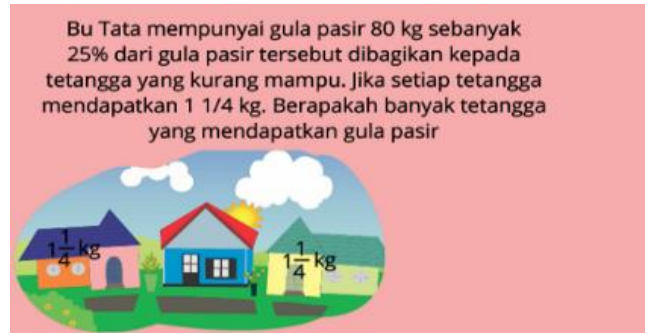

Tampilan soal 6

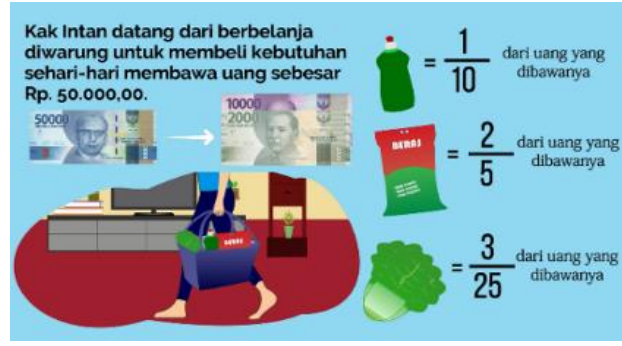

Tampilan soal 2

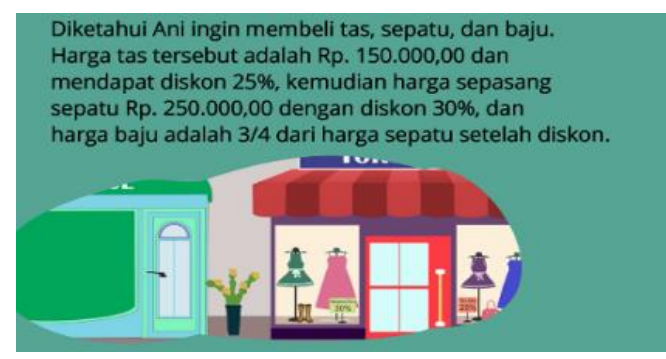

Tampilan soal 5

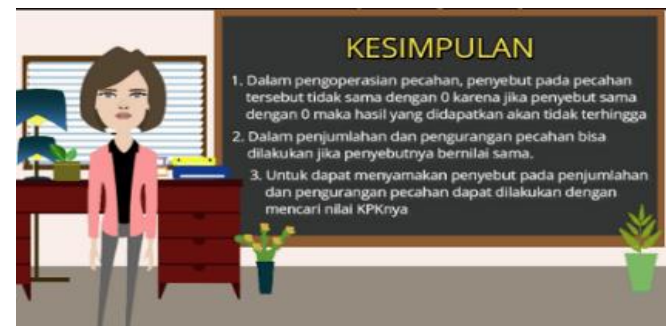

Tampilan kesimpulan

Gambar 1. Tampilan media video pembelajaran

\section{Pembahasan}

Penelitian pengembangan media video pembelajaran berbasis higher order thinking skills sudah melewati tahap uji review para ahli, uji coba perorangan dan kelompok kecil. Proses pengembangan media video pembelajaran berbasis HOTS menggunakan model ADDIE menyebabkan keefektifan media video pembelajaran mulai pada tahap analisis, desain, pengembangan, pemanfaatan dan evaluasi, serta perbaikan produk. menunjang keberhasilan pengembangan produk yang memperoleh kualifikasi sangat baik dan baik,. Media video pembelajaran layak digunakan dalam proses pembelajaran. Ditinjau dari aspek isi pembelajaran, validitas media video pembelajaran berada pada kualifikasi sangat baik. Jadi, tujuan pembelajaran dan format tujuan pembelajaran sudah sesuai dengan isi media video pembelajaran. Hal tersebut sesuai uraian yang menyatakan bahwa pembelajaran dengan tujuan yang jelas dapat dijadikan sebagai acuan dalam proses pembelajaran seperti harus memiliki audiens, perilaku, kondisi, dan tingkat penguasaan yang jelas(Ansyari, 2018; Arif \& Yeniawati, 2018). Perolehan kualifikasi sangat baik juga dapat tercapai karena kejelasan materi yang disajikan. Materi yang disajikan pada video pembelajaran sudah sangat jelas. Video dapat membantu pendidik dalam mengajarkan konsep materi dan menjelaskan hal abstrak menjadi konkret (Christ et al., 2017; Nurdin et al., 2019). Materi yang disajikan pada video pembelajaran sudah disajikan secara sistematis. Materi yang disusun secara sistematis dan variatif akan memudahkan siswa untuk memahami isi materi (Coles, 2019; Fatmala et al., 2017). Setelah menggunakan media video dalam materi pembelajaran, siswa mulai tertarik dan lebih memahami materi (Nurdin et al., 2019; Purbayanti et al., 2020).

Perolehan kualifikasi sangat baik dapat tercapai karena kesesuaian antara contoh dan pembelajaran HOTS. Hal ini dibuktikan dari hasil penilaian oleh ahli isi pembelajaran pada butir instrumen terkait kesesuaian contoh dengan pembelajaran HOTS. Video pembelajaran sudah sesuai dengan pembelajaran HOTS. Proses pembelajaran dengan HOTS ditunjukkan dengan kemampuan level C4, C5, atau C6 (Listiani \& Sulistyorini, 2021; Purwanto Soeprapto et al., 2020). Ditinjau dari aspek desain pembelajaran, validitas media video pembelajaran berada pada kualifikasi baik. Jenis teks, ukuran teks, kejelasan teks, dan kemenarikan sajian teks pada media video pembelajaran sudah tepat dan menarik. Menyajikan unsur gambar, tulisan dan suara pada sebuah media pembelajaran bisa meningkatkan perhatian, mampu 
memperoleh informasi kompleks ,dan mendorong siswa untuk memahami ide (Chiu et al., 2017; Kurniawati et al., 2019). Perolehan kualifikasi baik dapat tercapai karena media video pembelajaran dapat memberikan pemahaman pesan pembelajaran secara lebih bermakna. Jadi, dapat disimpulkan bahwa sajian media video pembelajaran mampu memberikan pemahaman pesan pembelajaran secara lebih bermakna. (Lange \& Costley, 2020; Meyera et al., 2019; Nashrullah et al., 2019) menyatakan bahwa materi yang disampaikan melalui media video dapat dengan mudah dimengerti siswa karena visual dan audionya di mana siswa memiliki sumber daya yang cukup untuk memilih, mengatur, dan mengintegrasikan pengetahuan baru ke dalam memori jangka panjang. Penggunaan media video pembelajaran, pembelajaran menjadi lebih efektif dan meningkatkan minat siswa untuk belajar (Agustini \& Ngarti, 2020; Hajhashemi et al., 2018).

Ditinjau dari aspek media pembelajaran, validitas media video pembelajaran berada pada kualifikasi sangat baik. Penyajian gambar pada media video pembelajaran ini sudah menarik dan penyajian gambar mampu memperjelas materi. Hal tersebut sesuai dengan pendapat dari (Gellerstedt et al., 2018; Hakim et al., 2019) yang menyatakan bahwa pembelajaran yang disajikan dengan gambar memudahkan siswa dalam memahami materi yang rumit. Perolehan kualifikasi sangat baik tercapai karena keteraturan musik, latar, dan ketepatan sound effect yang digunakan untuk menambah suasana dan melengkapi sajian visual dengan kriteria sangat baik. Keteraturan musik, latar, dan ketepatan sound effect yang digunakan dapat menambah suasana dan melengkapi sajian visual. Hal tersebut sesuai pernyataan bahwa keteraturan musik dapat mendukung kondisi belajar dan mengubah suasana pembelajaran (Hapsari \& Hanif, 2019; Panjaitan \& Hasanah, 2019). Perolehan kualifikasi sangat baik dapat tercapai dikarenakan kemenarikan sajian animasi. Animasi yang ditampilkan pada media video pembelajaran sudah disajikan secara menarik. Media dapat membangkitkan motivasi dan minat belajar melalui gambar dan animasi yang disajikan (Febriani, 2017; Gellerstedt et al., 2018; Yip et al., 2019). Pernyataan tersebut juga dibuktikan melalui hasil penelitian yang menyatakan bahwa penggunaan gambar dan animasi dalam pembelajaran dapat mengonkretkan berbagai konsep materi, meningkatkan motivasi, dan meningkatkan hasil belajar siswa (Pangestu et al., 2019; Rosnihayati, 2017).

Kelebihan media video pembelajaran ini yaitu mampu meningkatkan kemampuan berpikir tingkat tinggi, sehingga mampu meningkatkan hasil belajar siswa. Penelitian ini memiliki perbedaan dengan penelitian yang lain yaitu media video pembelajaran berbasis higher order thinking skills ini di dalamnya menyajikan animasi yang mampu menarik minat siswa untuk belajar. Selain itu, materi yang disajikan adalah materi operasi hitung pecahan pada mata pelajaran Matematika yang materinya berbeda dengan penelitian lain. Kelebihan tersebut dibuktikan dengan perolehan penilaian produk dengan kualifikasi sangat baik dan baik, sehingga layak digunakan dalam proses pembelajaran. Implikasi dari dikembangkannya media video pembelajaran berdampak terhadap minat belajar siswa serta memotivasi guru dalam mengembangkan media pembelajaran. Keterbatasan pengembangan media video pembelajaran ini hanya menyajikan materi yang berkaitan dengan operasi hitung pecahan mata pelajaran Matematika di kelas V di SD Negeri 1 Baktiseraga semester ganjil. Disarankan kepada peneliti lain agar mengembangan media yang lebih inovatif lagi dan memanfaatkan hasil penelitian ini sebagai referensi.

\section{SIMPULAN}

Media video pembelajaran berbasis higher order thinking skills ini berhasil dikembangkan dengan mengacu pada model ADDIE. Validitas media video pembelajaran berbasis higher order thinking skills ini memperoleh kualifikasi sangat baik dan baik, sehingga dinyatakan layak didasarkan dari hasil uji validitas pada aspek ahli isi pembelajaran, ahli desain pembelajaran, dan ahli isi media pembelajaran serta uji coba perorangan dan kelompok kecil. Dengan demikian, produk media video pembelajaran ini dapat dijadikan salah satu media pembelajaran yang tepat untuk memecahkan permasalahan pada pembelajaran Matematika kelas V.

\section{DAFTAR RUJUKAN}

Agung, A. A. G. (2017). Metodologi PenelitianKkuantitatif (Perspektif Manajemen Pendidikan). Singaraja: Universitas Pendidikan Ganesha.

Agustini, K., \& Ngarti, J. G. (2020). Pengembangan Video Pembelajaran untuk Meningkatkan Motivasi Belajar Siswa Menggunakan Model R\&D. Jurnal Imiah Pendidikan Dan Pembelajaran, 4(1), 62-78. http://dx.doi.org/10.23887/jipp.v4i1.18403.

Ansyari, M. F. (2018). Developing a Rubric for Assessing Pre-Service English Teacher Struggles with Instructional Planning. Cogent Education, https://doi.org/10.1080/2331186X.2018.1507175. 
Arif, \& Yeniawati. (2018). Pengantar Desain Pembelajaran. Jambi: Pustaka Ma'Arif Press.

Azmi, R. A., Rukun, K., \& Maksum, H. (2020). Analisis Kebutuhan Pengembangan Media Pembelajaran Berbasis Web Mata Pelajaran Administrasi Infrastruktur Jaringan. Jurnal Imiah Pendidikan Dan Pembelajaran, 4(2), 303-314. http://dx.doi.org/10.23887/jipp.v4i2.25840.

Cahyadi, R. A. H. (2019). Pengembangan Bahan Ajar Berbasis Addie Model | Cahyadi | Halaqa: Islamic Education Journal. HALAQA: Islamic Education Journal, 3(1), 35-43. https://doi.org/10.21070/halaqa.v3i1.2124.

Chiu, P.-S., Chen, H.-C., Huang, Y.-M., Liu, C.-J., Liu, M.-C., \& Shen, M.-H. (2017). A Video Annotation Learning Approach to Improve the Effects of Video Learning. Innovations in Education and Teaching International, 55(4), 459-469. https://doi.org/10.1080/14703297.2016.1213653.

Christ, T., Arya, P., \& Chiu, M. M. (2017). Video Use in Teacher Education: An international Survey of $\begin{array}{lllll}\text { Practices. Teaching } & \text { 22-35. }\end{array}$ https://doi.org/10.1016/J.TATE.2016.12.005.

Coles, A. (2019). Facilitating the Use of Video with Teachers of Mathematics: Learning from Staying with the Detail. International Journal of STEM Education, 6(5). https://doi.org/10.1186/s40594-018-0155y.

Daheri, M., Juliana, J., Deriwanto, D., \& Amda, A. D. (2020). Efektifitas WhatsApp sebagai Media Belajar Daring. Jurnal Basicedu, 4(4), 775-783. https://doi.org/10.31004/basicedu.v4i4.445.

Endriani, R., Sundaryono, A., \& Elvia, R. (2018). Pengembangan Media Pembelajaran Kimia Menggunakan Video untuk Mengukur Kemampuan Berpikir Kritis Siswa. PENDIPA Journal of Science Education, 2(2), 142-146. https://ejournal.unib.ac.id/index.php/pendipa/article/viewFile/4662/2552.

Fanani, A., \& Kusmaharti, D. (2018). Pengembangan Pembelajaran Berbasis HOTS (Higher Order Thinking Skill) di Sekolah Dasar Kelas V. Jurnal Pendidikan Dasar, 9(1).

Fatmala, N. E., Nyeneng, I. D. P., \& Suana, W. (2017). Pengembangan Modul Kontekstual Berbasis Multirepresentasi pada Materi Hukum Newton tentang Gravitasi. Jurnal Pembelajaran Fisika, 5(4). http://jurnal.fkip.unila.ac.id/index.php/JPF/article/view/13141.

Febriani, Co. (2017). Pengaruh Media Video terhadap Motivasi Belajar dan Hasil Belajar Kognitif Pembelajaran IPA Kelas V Sekolah Dasar. Jurnal Prima Edukasia, 5(1), 11-21. https://doi.org/10.21831/jpe.v5i1.8461.

Fitriani, N., Suryadi, D., \& Darhim, D. (2018). Analysis of Mathematical Abstraction on Concept of a Three Dimensional Figure with Curved Surfaces of Junior High School Students Recent Citations Analysis of Mathematical Abstraction on Concept of a Three Dimensional Figure with Curved Surfaces of Junior. Journal of Physics: Conference Series, 12037. https://doi.org/10.1088/17426596/1132/1/012037.

Gellerstedt, M., Babaheidari, S. M., \& Svensson, L. (2018). A First Step towards a Model for Teachers' Adoption of ICT Pedagogy in Schools. Heliyon, 4(9), 786. https://doi.org/10.1016/J.HELIYON.2018.E00786.

Hajhashemi, K., Caltabiano, N., Anderson, N., \& Tabibzadeh, S. A. (2018). Multiple Intelligences, Motivations and Learning Experience Regarding Video-Assisted Subjects in a Rural University. International Journal of Instruction, 11(1), 167-182. https://doi.org/10.12973/IJI.2018.11112A.

Hakim, A. L., Anggraini, Y., Fitriani, R., \& Haqiqi, A. K. (2019). Pengaruh Penggunaan Media Gambar dalam Pembelajaran Sejarah. Jurnal Transformatif (Islamic Studies), 3(2), 131-136. https://doi.org/10.23971/tf.v3i2.1353.

Haking, D. D., \& Soepriyanto, Y. (2019). Pengembangan Media Video Pembelajaran Renang pada Mata Pelajaran PJOK untuk Siswa Kelas V SD Article History. JKTP, 2(4), 320-328. https://core.ac.uk/download/pdf/287323758.pdf.

Hapsari, A. S., \& Hanif, M. (2019). Motion graphic animation videos to improve the learning outcomes of elementary school students. European Journal of Educational Research, 8(4), 1245-1255. https://doi.org/10.12973/eu-jer.8.4.1245.

Ichsan, I. Z., Iriani, E., \& Hermawati, F. M. (2018). Peningkatkan Keterampilan Berpikir Tingkat Tinggi (Higher Order Thinking Skills) pada Siswa Sekolah Dasar melalui Video Berbasis Kasus Pencemaran Lingkungan. Edubiotik: Jurnal Pendidikan, Biologi Dan Terapan, 3(2). https://doi.org/https://doi.org/10.33503/ebio.v3i02.175.

Kasri, K. (2018). Peningkatan Prestasi Belajar Matematika melalui Media Puzzle Siswa Kelas I SD. Jurnal Pendidikan : Riset Dan Konseptual, 2(3). https://doi.org/10.28926/riset_konseptual.v2i3.69.

Kurniawati, T., Setyosari, P., \& Kuswandi, D. (2019). Strategi Pembelajaran Nilai Karakter Mandiri Berbantuan Video Animasi Pembelajaran untuk PAUD. JINOTEP (Jurnal Inovasi Dan Teknologi Pembelajaran) Kajian Dan Riset Dalam Teknologi Pembelajaran, 6(1). https://doi.org/10.17977/um031v6i12019p030. 
Lange, C., \& Costley, J. (2020). Improving Online Video Lectures: Learning Challenges Created by Media. International Journal of Educational Technology in Higher Education 2020 17:1, 17(1), 1-18. https://doi.org/10.1186/S41239-020-00190-6.

Lestari, S. Z. D., \& Roesdiana, L. (2021). Analisis Kemampuan Berpikir Kritis Matematis Siswa SMP pada Materi Himpunan. MAJU: Jurnal Ilmiah Pendidikan Matematika, 8(1), 2579-4647. https://www.ejournal.stkipbbm.ac.id/index.php/mtk/article/view/611.

Listiani, W., \& Sulistyorini, Y. (2021). Kompetensi Pedagogik Mahasiswa Program Studi Pendidikan Matematika dalam Menyusun Tes Matematika HOTS. LAPLACE: Jurnal Pendidikan Matematika, 4(1), 99-106. https://doi.org/10.31537/laplace.v4i1.467.

Lubis, M. (2020). Peran Guru Pada Era Pendidikan 4.0. EDUKA : Jurnal Pendidikan, Hukum, Dan Bisnis, 4(2). https://doi.org/10.32493/eduka.v4i2.4264.

Melinda, V. A., Degeng, N. S., \& Kuswandi, D. (2018). Pengembangan Media Video Pembelajaran IPS Berbasis Virtual Field Trip (VFT) pada Kelas V SDNU Kratonkencong. JINOTEP (Jurnal Inovasi Dan Teknologi Pembelajaran): Kajian Dan Riset Dalam Teknologi Pembelajaran, 3(2), 158-164. http://dx.doi.org/10.17977/um031v3i22017p158.

Meyera, O. A., Omdahlb, M. K., \& Guido, M. (2019). Investigating the Effect of Pre-Training when Learning through Immersive Virtual Reality and Video a Media and Methods Experiment | Elsevier Enhanced Reader. Computers \& Education, 140,1-17. https://doi.org/10.1016/j.compedu.2019.103603.

Musthofa, U., \& Murdani. (2018). Efektivitas Penggunaan Media Pembelajaran Video Tutorial untuk Meningkatkan Kompetensi Menggambar 3D. Jurnal Pendidikan Teknik Mesin, 18(2). https://journal.unnes.ac.id/nju/index.php/JPTM/article/view/18662.

Nashrullah, N., Sulton, S., \& Soepriyanto, Y. (2019). Pengembangan Video Pembelajaran Adaptasi dan Cara Berkembang Biak Makhluk Hidup untuk Siswa Kelas VI Sekolah Dasar. Jurnal Kajian Teknologi Pendidikan, 1(4), 327-332. http://journal2.um.ac.id/index.php/jktp/article/view/7076.

Nguyen, T. M. T., \& Nguyen, T. huy L. (2017). Influence of Explicit Higher-Order Thinking Skills Instruction on Students' Learning of Linguistics. Thinking Skills and Creativity, 26, 113-127. https://doi.org/10.1016/J.TSC.2017.10.004.

Nurdin, E., Ma'aruf, A., Amir, Z., Risnawati, R., Noviarni, N., \& Azmi, M. P. (2019). Pemanfaatan Video Pembelajaran Berbasis Geogebra untuk Meningkatkan Kemampuan Pemahaman Konsep Matematis Siswa SMK. Jurnal Riset Pendidikan Matematika, 6(1), 87-98. https://doi.org/10.21831/jrpm.v6i1.18421.

Nurkamilah, M., Fahmi Nugraha, M., \& Sunendar, A. (2018). Mengembangkan Literasi Matematika Siswa Sekolah Dasar melalui Pembelajaran Matematika Realistik Indonesia. 2(2), 70.

Oktavian, R., \& Aldya, R. F. (2020). Efektivitas Pembelajaran Daring Terintegrasi di Era Pendidikan 4.0. Didaktis: Jurnal Pendidikan Dan Ilmu Pengetahuan, 20(2). https://doi.org/10.30651/didaktis.v20i2.4763.

Pangestu, R. D., Mayub, A., \& Rohadi, N. (2019). Pengembangan Desain Media Pembelajaran Fisika SMA Berbasis Video pada Materi Gelombang Bunyi. Jurnal Kumparan Fisika, 1(1), 48-55. https://doi.org/10.33369/JKF.1.1.48-55.

Panjaitan, D. J., \& Hasanah, D. N. (2019). Musik Mozart sebagai Pengiring Pembelajaran untuk Meningkatkan Motivasi dan Belajar Matematika. Jurnal MathEducation Nusantara, 3(1), 40-48. https://doi.org/10.32696/JMN.V3I1.109.

Pasandaran, R. F. (2018). Taksonomi SOLO (Structure of Observed Learning Outcomes) sebagai Assessment Autentik untuk Membangun Kemampuan Literasi Mahasiswa dalam Mengidentifikasi Grafik Fungsi Trigonometri. Jurnal Penelitian Matematika Dan Pendidikan Matematika, 1(1). http://journal.uncp.ac.id/index.php/proximal/article/view/850.

Pratama, G. S., \& Retnawati, H. (2018). Urgency of Higher Order Thinking Skills (HOTS) Content Analysis in Mathematics Textbook Recent Citations Urgency of Higher Order Thinking Skills (HOTS) Content Analysis in Mathematics Textbook. Journal of Physics: Conference Series, 12147. https://doi.org/10.1088/1742-6596/1097/1/012147.

Purbayanti, H. S., Ponoharjo, P., \& Oktaviani, D. N. (2020). Analisis Kebutuhan Video Pembelajaran Matematika pada Pandemi Covid-19. JIPMat, 5(2), 165-172. https://doi.org/10.26877/jipmat.v5i2.6693.

Purwanto Soeprapto, A., Kurniawan, E., Purwanto, A., Zajuli Ichsan, I., Ali, A., \& Kaur Swaran Singh, C. (2020). ESBOR: Analysis Students HOTS for Develop Digital Technology in Environmental Learning. International Journal of Advanced Science and Technology, 29(4), 3896-3904. http://sipeg.unj.ac.id/repository/upload/similarity/ESBOR_Analysis_Students_HOTS_for_Develo p_Digital_Technology_in_Environmental_Learning.pdf. 
Rahman, A., Aryani, F., \& Sinring, A. (2019). Pengembangan Media Video Bimbingan Konseling untuk Mengurangi Perilaku Bullying. Jurnal Psikologi Pendidikan Dan Konseling: Jurnal Kajian Psikologi Pendidikan Dan Bimbingan Konseling, 4(2). https://doi.org/10.26858/jpkk.v4i2.5002.

Rosnihayati, R. (2017). Penggunaan Media Gambar untuk Meningkatkan Hasil Belajar Ips Siswa Kelas II SDN 003 Pagaran Tapah Darussalam Kabupaten Rokan Hulu. Primary: Jurnal Pendidikan Guru Sekolah Dasar, 6(1). https://doi.org/10.33578/jpfkip.v6i1.4110.

Soimah, I. (2018). Pengaruh Media Pembelajaran Berbasis Komputer terhadap Hasil Belajar IPA Ditinjau dari Motivasi Belajar Siswa. Natural: Jurnal Ilmiah Pendidikan IPA, 5(1), 38-44. https://doi.org/10.30738/NATURAL.V5I1.2559.

Suryawan, I. G. P., Suwatra, I. I. W., \& Sumantri, M. (2017). Pengaruh Model Pembelajaran Sscs Berbantuan Kartu Masalah terhadap Kemampuan Pemecahan Masalah Matematika Siswa Kelas III SD di Gugus XIII Kecamatan Buleleng. MIMBAR PGSD Undiksha, 5(2), 2017. http://dx.doi.org/10.23887/jjpgsd.v5i2.10664.

Susanto, A. (2017). Manajemen Peningkatan Kinerja Guru (Konsep, Strategi, dan Implementasi). Jakarta: Pernada Media Group.

Susilo, S. V. (2020). Penggunaan Media Pembelajaran Berbasis Audio Visual untuk Meningkatkan Hasil Belajar Bahasa Indonesia di Sekolah Dasar. Jurnal Cakrawala Pendas, 6(2). https://doi.org/10.31949/jcp.v6i2.2100.

Syafi'i, I., Sa'diyah, C., Wakhidah, E. W., \& Umah, F. M. (2020). Penerapan Video Pembelajaran Daring Anak Usia Dini pada Masa Pandemi Covid-19. Al-Athfaal : Jurnal Ilmiah Pendidikan Anak Usia Dini, 3(2). http://www.ejournal.radenintan.ac.id/index.php/al-athfaal/article/view/7315.

Tegeh, I. M., \& Jampel, I. N. (2017). Metode Penelitian Pengembangan. Singaraja: Universitas Pendidikan Ganesha.

Usman, S. D., \& Husnan, R. (2020). Efectivitas Penerapan Media Video Pembeajaran pada Mata Pelajaran Mekanika Teknik. Educational Building Jurnal Pendidikan Teknik Bangunan Dan Sipil, 6(2 DES), 5965. https://doi.org/10.24042/ajipaud.v3i2.7315.

Utaminingtyas, S. (2020). Implementasi Problem Solving Berorientasi Higher Order Thingking Skill (Hots) Pada Pembelajaran Ips Sekolah Dasar. Jurnal Ilmiah Pendidikan Dasar, 7(2), 84-98. http://dx.doi.org/10.30659/pendas.7.2.84-98.

Wirasasmita, R. H., \& Putra, Y. K. (2018). Pengembangan Media Pembelajaran Video Tutorial Interaktif Menggunakan Aplikasi Camtasia Studio dan Macromedia Flash. Edumatic: Jurnal Pendidikan Informatika, 1(2), 35-43. https://doi.org/10.29408/edumatic.v1i2.944.

Yip, J., Wong, S. H., Yick, K. L., Chan, K., \& Wong, K. H. (2019). Improving Quality of Teaching and Learning in Classes by Using Augmented Reality Video. Computers \& Education, 128, 88-101. https: //doi.org/10.1016/J.COMPEDU.2018.09.014.

Zaluchu, S. E. (2020). Strategi Penelitian Kualitatif dan Kuantitatif di dalam Penelitian Agama. Evangelikal: Jurnal Teologi Injili Dan Pembinaan Warga Jemaat, 28(1), 28-38. https://core.ac.uk/download/pdf/296974333.pdf. 